\title{
Liberation or predicament: controversy of OLD AGE concept (based on a newspaper opinion article and readers' comments)
}

\author{
I. Alyeksyeyeva \\ National Taras Shevchenko University of Kyiv, Department of English philology and cross-cultural communication, Kyiv \\ Corresponding author. E-mail: irene.alexeyeva@gmail.com
}

Paper received 30.08.19; Revised 06.09.19; Accepted for publication 11.09.19.

https://doi.org/10.31174/SEND-Ph2019-204VII60-01

\begin{abstract}
The study examines language means used in a newspaper publication and readers' comments to identify the connotations of the OLD AGE concept as well as attitudes to the elderly and their social status in the UK society. Though the opinion article admits negative connotations of the concept, the author focuses on senior citizens' liberation from social conventions and clear-cut identity that may be considered slots of the concept. In their comments, the audience acknowledges these advantages, yet emphasizes that these may be seriously affected by such phenomena (slots) as health, wealth, loneliness and absence of prospects. The study sheds light on the complexity of this age group as well as on the ideology that, according to the readers, shapes the attitude to the elderly and their social status.
\end{abstract}

Keywords: concept, slot, idiom, (contextual) antonym, meaning, connotation.

Introduction. At present, the industrialized countries face a number of problems. Among the troublesome issues, there are radical demographic changes. While the population growth drew specialists' attention in the late $20^{\text {th }}$ century, the key challenge of the $21^{\text {st }}$ century is shifting to the ageing population. In the United States, for example, the proportion of people aged 65 or older tripled (from $4 \%$ to $12 \%$ ) between 1900 and 2000 and was $15.6 \%$ in 2017 [15]. In the UK, in 2017, over $18 \%$ of the population were aged 65 years or over, compared with almost $16 \%$ in 2007; this is projected to grow to nearly $21 \%$ by 2027 [15].

The increased longevity entails a number of social changes, namely the family structure and shifts in the employment and production spheres. The elderly used to be focused on familial relations. Yet, since the family in industrialized countries has transformed from a unit encompassing several generations living in close proximity to self-contained nuclear families of only parents and young children, senior citizens have become isolated from younger people and each other. In addition, the industrialized countries have seen a continual introduction of technology that requires from workforce special training and education as well as modifies dominant mores, expectations and definitions of the quality of life. As a result, formal education, which usually takes place in the early years and forms collective opinions and mores, tends to enhance the difficulties in adapting to old age [13]. It should be noted in passing that the influence of technology is so remarkable that technological innovations have started to define certain generations, which may be observed in the term iGeneration/iGen used to refer to people born in the mid-1990s and the early 2000s to be digitally native and surrounded by screens of iPhones and iPads.

'The elderly' group is not monolithic: rather than lumping together all people who have been defined as old, gerontologists have recognized the diversity of old age by defining sub-groups. Forman et al., for example, distinguishes the young old (60 to 69), the middle old (70 to $79)$, and the very old (80+) [7]. Describing sub-groups in the $65+$ population enables a more accurate portrayal of significant life changes [14].

The goal. The research aims at looking into online
British communication on old age and ageing in order to distinguish recurring language means and, consequently, the key concept and their slots as well as attitudes that permeate this discourse. The results of the study will help to comprehend better the structure of the OLD AGE concept, it sheds light on the peculiarities of (inter)generational communication as well as the social structure in the UK.

Materials and Methods. Besides deductive and inductive content analysis, the methods employed in the research included semantic, cognitive, contextual and interpretive content analyses. The study is based on the article Why does no one ever tell you how brilliant ageing can be? by Suzanne Moore published in The Guardian's Opinion Section August 20, 2019 [18]. The provocative title of the article and its content sparkled a discussion among the readers who left as many as 987 comments within the two days after the publication. The article analyses both Suzanne Moore's text and the comments.

A brief review of publications on the subject. As it has already been mentioned, the problems of ageing population have recently been seen as central. The sciences that deal with the phenomenon are from the medical field, such as gerontology, geriatrics, nursing, and psychiatry, to name just a few (see, for example, [5; 8; 10]). Yet, starting from the early 1990s, the list of disciplines has been considerably extended and embraced sociology, psychology, and communication studies (see $[6 ; 9 ; 12$; 17]).

Linguistic studies mainly belong to the sphere of cognitive linguistics, lexicology, comparative linguistics, and Cultural Studies: OLD AGE and the related oppositional concepts OLD and YOUNG have been selected as the pivotal and described in detail and/or compared on the material yielded from various languages $[1 ; 2 ; 3 ; 4]$. The ambition of the article lies in investigating the meanings, connotations and attitudes that have surfaced in the Guardian's feature and the audience's reaction to this provocative mass media text on social and psychological processes associated with ageing.

Results and discussion. For a couple of days, the article Why does no one ever tell you how brilliant ageing can be? by Suzanne Moore has been one of the most read features. This may be due to the eye-catching oxymoron 
brilliant ageing in the title: the very question implies that ageing typically is not seen as anything brilliant and a number of comments back up this idea. The verbal form varies from the diplomatic and idiomatic the writer has her head in the clouds (laerpeek) and argumentative comparison expressed in a rhetorical question Because on balance it's not, on the whole. Who would rather be 72 than 22? (Oldscarborian) to straightforward, at times vulgar Because it's not (HorseGas)/Because it's shit (becosthenite) and ironic coinage that implies almost equal negative nature of the processes Well, "ageing" is great, but wait until "deathing”, that's a blast I hear (StarOZamolxis).

After the provocative title, the author continues with the subtitle (In later life, you know what sparks joy: loving new things, discarding old things. It's finally time to live as you want to live, not as you're told you should), where later life becomes a synonym of old age and where the reader finds the abundance of contrasting actions and behaviours verbalized by antonyms - paradigmatic or contextual: loving - discarding, new - old, you want you're told you should. The contrast implies a radical change that takes place as one advances to the next stage in life, while the semantics of the lexemes in contrasting pairs conveys the idea of positive changes.

Mocking the content of the popular Edinburgh fringe, Moore assumes a role of a critical observer, who watches others enjoying the poor-quality performances from a distance and whom the age sets free to show her genuine opinion. She writes that, even though life after 50 is assumed to be awful, as we are all bitter hags or old farts, even though the Google results for signs of ageing will be about skincare, diet and exercise, even though one does not have a chance to get Carol Vorderman's arse and Lana Del Rey's lips and Kim Kardashian's waist and least of all to stay for ever young, the idea that life after 50 (another synonym for old age) brings liberation from social restraints becomes the key argument in its favour. Moore suggests seeing later years as the stage of full acceptance of one's self in its entirety, from physical body to psychological makeup, life experience and memories. To affirm this, she quotes Ursula K. Le Guin: "I am not 'in' this body. I am this body. Waist or no waist... Erase my age, you erase my life - me."

Having embraced oneself, one starts seeing old age as process of editing, i.e. dropping people, activities, and social duties that do not spark joy. This means adopting the hedonistic approach to life: old age, when one need not get up each weekday morning and go to work, when one can afford to ignore certain social expectations, turns into time for wasting: Time is what you make of it. You choose. Wasting is this context does not mean 'spending time uselessly' but rather 'spending time in activities that bring no material gain'. The freedom to do away with constraints coupled with self-awareness makes reasonable the conclusive remark of the article: The best sign of ageing, though, is that you are still you - only more so (it is noteworthy that the tautology you are you acquires a new meaning due to the particle still that implies at some point, you will cease to be you. Only more so emphasizes once again liberation from all the restrictions that limit people from birth to middle age).

The readers' comments (and their number, almost a thousand, proves that the article has hit the target and resonated with the audience) may be divided into friendly and oppositional. Their analysis may reveal attitudes and connotations that spring up when one hears of old age.

The supportive commentators confirm the main points made by Moore, i.e. enjoying freedom from troubles, work and social conventions: I just love it when I get carded and have to prove I'm over 65 to get the senior discount. Not as strong as I used to be, so hired a brilliant handyman who parades around my garden shirtless. Best excuse for getting out of tiresome events, I can't drive at night. No longer have to wear business attire and live in cutoff jeans. Get up at noon and go to bed when I like it. 70 is pretty good. (Valleyguri) Yes there are some not so great aspects but life gets better. (...) I know what I like, who I care for and what I want with such clarity now I have passed beyond 50. Everything else falls into the "life is now truly too short" category. (Lesleyontheleft) The only real benefit of getting old (amongst plethora of downsides) is that you don't care as much, particularly about what other people think (SillyRestrictions).

However, the opponents to the article outnumber its supporters. Firstly, many readers point out the vagueness of the term old age and intuitively feel the old age subgroups put forward by gerontologists: its interesting what age people define as "older". So what is "old"? (sanfairyanne); When you are looking back at your $\underline{50 \mathrm{~s}, 60 \mathrm{~s}}$ and 70s, you know that there can be as great a difference between being 55 and 75 as there is between being 15 and 35 (Ag Tigress); It depends what age we're talking about. 60, 70? Probably fine. Late 70's, 80's chances are you're running into trouble (bleacher1). As a result, old age appears to be an umbrella word for quite a vast lifespan and, consequently, may be experienced differently at certain points: Suzanne, you're enjoying yourself because you're not properly old.(...) Come back when you're 80 and tell us what you think. It may be different (Felicie); Now can we please have an article by someone in their

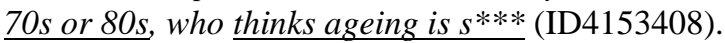

The factor that makes connotations of old age negative is health issues and the lexeme health keeps reappearing in many comments: growing older and living life to the full can very much depend on retaining good health (WalterBMorgan). Yet, in many comments, health issues are combined with one's financial predicament: ....many older people have had to give up favourite hobbies due to illness, or are in constant pain. Many lose dignity in old age due to what the ageing process does to us all eventually, or cannot afford to heat their homes properly (RebelJ); ...ageing has many advantages but only if you can afford to be old. Too many elderly people live hand to mouth with constant worries over food, shelter and care which make day to day living extremely challenging (SAMcG); If you're happy now you're older, it's probably down to your current wealth/health circumstances and has nothing to do with your actual age. Being skint, 65, having arthritis or cancer and living in a shitty council flat on the $14^{\text {th }}$ floor with a bunch of nutters living next door having constant all night parties is not brilliant. Though I'm sure plenty of early-retiree's living in lovely houses in Hampshire, with big pensions and regular holidays in the South of France would say otherwise (HorseGas). HorseGas comments is based on contrast verbalized by the follow- 
ing (sometimes contextual) antonyms: skint - with big pensions, 65 - early retiree, shitty council flat on the $14^{\text {th }}$ floor - lovely houses. Poverty may strip the aged of the privilege to waste time because they have to go on working in the 70s: (Why does no one ever tell you how brilliant ageing can be?) Presumably because working into your mid 70s whilst not able to afford any assets to enjoy later life brings little to no joy (FirmAndUnfair).

The correlation between senior citizens' quality of life in old age and their financial situation is summed up in the following comment: Seriously, ageing is good because, if you have enough money, you can use your time for personal development and doing things you enjoy, without stress. It's bad because there's a lot of prejudice against old folk in the UK, upcoming pensioners who don't own a home will be unable to house themselves because they can't afford to pay the rent, benefits for the elderly are under attack, and lots of folk die because they can't afford their heating bills (heian555).

Another association evoked by ageing is loneliness: The not so nice thing about growing old is losing ones friends, I am well into my eighties and I have very fond memories of days gone by. Sometimes it is nice to live in the past, in your memory, when we were all young and everything was rosey and there seemed to be a nice future ahead of us. Dreams are also nice, when you see and talk to all those who have now gone. Old age can also be lonely, I depend now on the television for company (Tommy8); The new found freedom is a positive experience for some, but not for others. So many are alone and lonely. So many others are being neglected and bullied in so called 'care' homes (Synnicc).

Nevertheless, there are several comments of those whose freedom to dispose of their time the way they want has been taken away due to familial duties, which is implied in the following message: At 66 years of age I find no resonance whatsoever with any of the points in $\mathrm{Su}$ zanne's article. Maybe Suzanne isn't the typical modern grandparent. Maybe she doesn't have the grandkids twice a week (Azibobo). Being a typical modern grandparent who has grandchildren twice a week does not suggest any freedom or enjoyment and appears to be very much just another job.

The following dialogue leads us to yet to another aspect of old age:

excathedra: (Why does no one ever tell you how brilliant old age can be? ) It is if you got money. And reasonably good health. And reasonably good mobility. And aren't lonely. And aren't isolated.

Dididonnews: You can have all those problems at 30.

Bill254: Yes, but at 55 and without money you just know you aren't going to make it.

The conversation reveals that the liberating feature of old age, i.e. absence of term-long prospects, afflicts the deepest misery: Living in a residential care home with prescribed getting up times, shower times, meal times. Trouble getting around. Finding the money to pay for everything. Trouble remembering stuff. Living with other old people and realising you've actually regressing to being a child only there's no future to look forward to (bleacher1). Yet, even this seems to be put down to money or lack of it: When I was younger I always had hopes, dreams to fulfil. Now at sixty I realise that getting older is nothing to look forward to, unless you are financially able to live well. Mortgage paid off, second home in France, and a healthy occupational pension, supplemented by a generous state pension plus free public transport and winter heating allowances help (Lottielou). Yet, some commentators are so sceptical about the humanity's future in general that they see their lack of prospects as blessing in disguise, for example: Looking at the news last night, my husband (69) said to me "I'm glad I'm old". I (67) replied "me too" (Linda Ellis).

The readers do not hesitate to point out that, despite ever growing number of the elderly citizens, the society treats them with neglect: I utterly loathe being treated as if I were invisible when I line up with others for service, and they are acknowledged, and I am not. Does that happen all the time; of course not! But it happens with age and I'm damn sure others here know it (Sinnicc).

The negative attitude to old age is attributed to the ideology of the modern UK and the world in general, the ideology that values citizens as workforce and is in a hurry to write them off as soon as they stop producing anything and become a strain on the social welfare system: The free market (neoliberalism) values youth and energy over age and wisdom, willingness to change over experience. The aged are an unproductive drain on the economy which is why they are hated and reviled in the UK. Unless they are rich in which case they are wonderful role models for young people... We live in a cult of youth created by political/ economic ideology. The old are either rich, off to Dignitas, on the checkout at Tesco or homeless (airmonkey1001). Modern communication technologies facilitate dissemination of this worldview by broadcasting public figures that follow this trend: I notice Mr Trump uses a considerably younger photo of himself on his twitter profile. And he doesn't seem alone in that... (BiscuitsBrown). The urge to pursue and prolong one's youth is also hyped by industries that sell 'rejuvenating products' and, therefore, capitalize on the cult: (Why does no one ever tell you how brilliant old age can be?) ...because chasing Youth is the carrot dangling from the stick and in its pursuit we are willing to part with lots of money. It's the same for weight (Simother). The manipulative nature and futility of the 'forever-young' ambition is expressed with the metaphor the carrot dangling from the stick.

Conclusions. The society of western industrialized countries is becoming ever more fragmented. In addition to such categories as ethnicity, religion, race, modern societies consist of more age groups than they used to as a result of ever increasing longevity (in 1980-1982, it was on average 70 years in the UK, in 2015-2017 the data showed the increase up to 78 years). The analysis of the newspaper title targets negative connotations inherent in the concept OLD AGE, yet the newspaper article argues that old age is a positive stage in life marked by one's clear-cut identity and liberation from social restrictions. The audience, however, is critical of this message: though the commentators support the idea of freedom from society's pressure and integrity of one's identity in later years, the downside that may not compensate for the upside is such slots of the concept as physical frailty and illness, financial predicament, loneliness and absence of prospects. The discussion also reveals the intuitive sub- 
categorization of old age (namely, one's 50's, 60's, etc.), where each stage is different in terms of possibilities, expectations and perception, which is backed up by the current scientific research. The society's attitude to the concept OLD AGE and the elderly as social group are shaped by the modern ideology broadcast with the help of mass media and based on the materialistic values.

\section{REFERENCES}

1. Блинова И.С. Концепт «старость» в русской и немецкой лингвокультурах: 10.02.20 «Сравнительно-историческое, типологическое и сопоставительное языкознание». Волгоград, 2009. - 210c.

2. Калько, В. Концепти молодість та старість в українській мові (на матеріалі паремій) // Лінгвістичні студії: збірник наукових праць - Режим доступу: http://litmisto.org.ua/?p=9265

9. Hummert, M.L., Atkinson, J.L., Garstka, T.A., Henry, C. (1998). Communication with Older Adults. The Influence of Age Stereotypes, Context, and Communicator Age // Human Communication Research. Vol.25 (1), p.124-151

10. Kotter-Grün, D. (2015). Changing Negative Views of Aging: Implications for Intervention and Translational Research // Annual Review of Gerontology and Geriatrics. Vol.35 (1)

11. National life tables, UK: 2015 to 2017. Retrieved from https://www.ons.gov.uk/peoplepopulationandcommunity/birt hsdeathsandmarriag-

es/lifeexpectancies/bulletins/nationallifetablesunitedkingdom/ 2015 to2017 картинах мира: дис. на соискание науч.степени кандидата филол.наук.: 10.02.20 «Сравнительно-историческое, типологическое и сопоставительное языкознание». - СПб, 2009. - 215c.

4. Рудакова О.И. Концепты «МОЛОДОСТЬ» и «СТАРОСТЬ» как динамические явления (на материале словообразования) // Вестник Ставропольского государственного университета. Филологические науки. - 2007. Вып.51. - С.247-252

5. Barnett, M. M., \& Adams, C. M. (2018). Ageism and aging anxiety among young adults: relationships with contact, knowledge, fear of death, and optimism // Educational Gerontology, Vol.44 (11), p.693-700

6. Coupland, N., Coupland, J., \& Giles, H. (1991). Language, society and the elderly. - Oxford. $-220 \mathrm{p}$

7. Forman, D. E., Berman, A. D., McCabe, C. H., Baim, D. S., \& Wei, J. Y. (1992). PTCA in the elderly: The "young-old" versus the "old-old""// Journal of the American Geriatrics Society. Vol.40 (1), p.19-22

8. Graciun, Catrinel. The Politics of Positive Aging // Quartier und Demokratie. - Springer, 2019. - S.35-52

12. Nussbaum, Jon F., \& Coupland, Justine. (2004). Handbook of Communication and Ageing Research. Routledge. - 624p.

13. Old age // Britannica. Retrieved from https://www.britannica.com/science/old-age

14. Old age // Wikipedia. Retrieved from https://en.wikipedia.org/wiki/Old_age

15. Overview of the UK population. Office for National Statistics. Retrieved from https://www.ons.gov.uk/peoplepopulationandcommunity/pop ulationandmigra-

tion/populationestimates/articles/overviewoftheukpopulation/ november 2018

16. Share of old age population (65 years and older) in the total US population from 1950 to 2050 . Retrieved from https://www.statista.com/statistics/457822/share-of-old-agepopulation-in-the-total-us-population/

17. Williams, Angie, \& Nussbaum, Jon F. (2013). Intergenerational Communication Across Life Span. - Routledge. 360 p.

\section{ILLUSTRATIVE MATERIAL}

1. Moore, S. (2019). Why does no one ever tell you how brilliant ageing can be? The Guardian. August 20. Retrieved

from

https://www.theguardian.com/commentisfree/2019/aug/20

/why-does-no-one-ever-tell-you-how-brilliant-ageing-canbe\#comments

\section{REFERENCES}

1. Blinova I.S. Concept 'old age' in Russian and English linguocultures: dissertation... of candidate of Philological Sciences: 10.02.20. - Volgograd, 2009. - 210p.

2. Kalko V. Concepts youth and old age in the Ukrainian language (based on proverbs) // Linguistic studies: collection of scientific works. Retrieved from http://litmisto.org.ua/?p=9265

3. Pintova A.A. Concepts OLD/YOUNG and
СТАРЫЙ/МОЛОДОЙ in English and Russian pictures of the world: dissertation... of candidate of Philological Sciences: 10.02.20. - Saint Petersburg, 2009. - 215p.

4. Rudakova O.I. Concepts YOUTH and OLD AGE as dynamic phenomena (based on word formation) // Collection of articles of Stavropol state university. Philological sciences. 2007. - \#51. - P.247-252 